\title{
Cellular diamine levels in cancer chemoprevention: modulation by ibuprofen and membrane plasmalogens
}

\author{
Paul L Wood ${ }^{1 *}$, M Amin Khan², Tara Smith² and Dayan B Goodenowe ${ }^{2}$
}

\begin{abstract}
Background: To develop effective strategies in cancer chemoprevention, an increased understanding of endogenous biochemical mediators that block metastatic processes is critically needed. Dietary lipids and nonsteroidal anti-inflammatory drugs (NSAIDs) have a published track record of providing protection against gastrointestinal malignancies. In this regard, we examined the effects of membrane plasmalogens and ibuprofen on regulation of cellular levels of diamines, polyamine mediators that are augmented in cancer cells. For these studies we utilized Chinese hamster ovary (CHO) cells and NRel-4 cells, a CHO cell line with defective plasmalogen synthesis.

Results: NRel-4 cells, which possess cellular plasmalogen levels that are $10 \%$ of control CHO cells, demonstrated 2to 3 -fold increases in cellular diamine levels. These diamine levels were normalized by plasmalogen replacement and significantly reduced by ibuprofen. In both cases the mechanism of action appears to mainly involve increased diamine efflux via the diamine exporter. The actions of ibuprofen were not stereospecific, supporting previous studies that cyclooxygenase (COX) inhibition is unlikely to be involved in the ability of NSAIDs to reduce intracellular diamine levels.

Conclusions: Our data demonstrate that ibuprofen, a drug known to reduce the risk of colorectal cancer, reduces cellular diamine levels via augmentation of diamine efflux. Similarly, augmentation of membrane plasmalogens can increase diamine export from control and plasmalogen-deficient cells. These data support the concept that membrane transporter function may be a therapeutic point of intervention for dietary and pharmacological approaches to cancer chemoprevention.
\end{abstract}

Keywords: CHO, NRel-4, ibuprofen, plasmalogens, omega-3 fatty acids, PPI-1011, putrescine, cadaverine, diamine exporter, ornithine decarboxylase, cancer chemoprevention

\section{Background}

While the focus of cancer research has largely involved the design of cytotoxic molecules, increasing efforts are being made to understand and utilize endogenous anticancer mechanisms. Areas of focus include dietary supplementation, identification of endogenous anticancer metabolites [1,2] and deregulation of polyamine catabolism [3,4]. Chemoprevention against colorectal [5-9] and prostate $[10,11]$ neoplasia has been demonstrated with

\footnotetext{
* Correspondence: paul.wood@lmunet.edu

'Dept. of Pharmacology, DeBusk College of Osteopathic Medicine, Lincoln Memorial University, 6965 Cumberland Gap Pkwy., Harrogate, TN 37752 USA Full list of author information is available at the end of the article
}

aspirin and some NSAIDs, like ibuprofen and sulindac, as well as with difluoromethylornithine (DFMO), an ornithine decarboxylase (ODC) inhibitor that decreases polyamine biosynthesis.

While aspirin and NSAIDs act to decrease local inflammation via cyclooxygenase (COX) inhibition, they also produce large decreases in the levels of the polyamines spermidine, putrescine and cadaverine, actions that are independent of COX inhibition [12]. Homeostatic regulation of intracellular polyamine and diamine levels is essential for normal cell growth and restriction of hyperplasia and neoplasia. Regulation of diamine levels is achieved by multiple points of physiological

\section{Biomed Central}


regulation. These include: $i)$ the rate limiting enzyme ODC that converts ornithine to putrescine [13,14]; ii) polyamine metabolism by polyamine oxidase, spermine oxidase and spermine/spermidine acetyltransferase $[15,16]$; iii) polyamine uptake [17]; and iv) diamine export $[17,18]$.

Complex changes in plasmalogens and fatty acid precursors of plasmalogens have been reported for cancer cells and the plasma of cancer patients [19]. Dietary omega-3 fatty acids, which are utilized in plasmalogen synthesis, are also known to decrease the risk of several cancers $[20,21]$. Decrements in plasmalogen levels, alterations in deacylation-reacylation of plasmalogens, and potential alterations in transport of plasmalogens, resulting from increases in scramblase 1 , have all been reported to potentially contribute to neoplasia $[22,23]$. In this regard, we have studied plasmalogen deficiency in NRel-4 cells [24-26], a CHO cell mutant not expressing dihydroxyacetone-phosphate acyltransferase (EC 2.3.1.42), a peroxisomal enzyme essential for plasmalogen synthesis. These cells possess plasmalogen levels that are 5 to $10 \%$ of those measured in control $\mathrm{CHO}$ cells [25]. In a targeted metabolomics analysis utilizing four GC-MS panels that assay over 200 metabolic intermediates in amino acid, nucleotide, alcohol, sugar, polyol, fatty acid, and organic acid pathways [26], we observed that N-Rel cells had large increases in the intracellular diamines putrescine and cadaverine. In this study we report our findings regarding the effects of plasmalogen replacement [27] and of ibuprofen treatment on cellular levels of diamines, diamine synthesis, and diamine exporter function in $\mathrm{CHO}$ [28] and NRel [24] cells.

\section{Materials and methods Tissue Culture}

$\mathrm{CHO}$ and NRel-4 cells (generous gift of Dr. R.A. Zoeller, Boston University) were cultured $\left(10 \mathrm{~cm}^{2}\right.$ plates $)$ in DMEM:F12 (Mediatech) supplemented with 10\% FBS (Invitrogen) and 1\% antibiotic/antimycotic (Invitrogen). Cells were grown at $37^{\circ} \mathrm{C}$ in a $5 \% \mathrm{CO}_{2}$ incubator and treated with ibuprofen or PPI-1011, an ether lipid plasmalogen precursor, in DMSO at $80 \%$ confluence. At the conclusion of incubations, the wells were washed twice with cold phosphate buffered saline (PBS) and the plates harvested with versene/Trypleexpress and stored at $-80^{\circ}$ C until analyzed.

\section{Putrescine Release}

Cells were incubated with DMSO (0.05\% final), ibuprofen $(10 \mu \mathrm{M})$ or PPI-1011 $(50 \mu \mathrm{M})$ for $48 \mathrm{hr}$. Next the cells were washed with PBS and incubated in Hank's Balanced Salt Solution (HBSS) containing $700 \mu \mathrm{M}$ arginine, to support cellular ornithine synthesis, and $15 \mathrm{mM}$
HEPES (pH7.4) for $1.5 \mathrm{hr}$. The medium was collected, spiked with $\left[{ }^{2} \mathrm{H}_{4}\right]$ putrescine, dried with a centrifugal evaporator and assayed for released putrescine. Cells were harvested and the released putrescine expressed as a percentage of the total cellular pool of putrescine.

\section{Putrescine Synthesis}

Cells were incubated with $100 \mu \mathrm{M}\left[{ }^{13} \mathrm{C}_{5}\right]$ ornithine in HBSS containing $700 \mu \mathrm{M}$ arginine and $15 \mathrm{mM}$ HEPES (pH7.4) for $30 \mathrm{~min}$. Cells were washed with cold PBS and harvested as described above, prior to measurement of cellular $\left[{ }^{13} \mathrm{C}_{5}\right]$ ornithine and $\left[{ }^{13} \mathrm{C}_{4}\right]$ putrescine pools.

\section{Diamine Quantitation}

Cells were sonicated in $1.2 \mathrm{ml}$ of acetonitrile:MeOH:formic acid (800:200:2.4) containing $\left[{ }^{2} \mathrm{H}_{4}\right]$ putrescine, $\left[{ }^{2} \mathrm{H}_{4}\right]$ cadaverine and $\left[{ }^{2} \mathrm{H}_{5}\right]$ ornithine (Cambridge and $\mathrm{CDN}$ Isotopes) as internal standards. For the putrescine synthesis experiments, $\left[{ }^{2} \mathrm{H}_{4}\right]$ cadaverine was used as the internal standard. The cell lysates were transferred to $1.5 \mathrm{ml}$ microtubes, sonicated and centrifuged at $4^{\circ} \mathrm{C}$ and 25,000 $\times \mathrm{g}$ for $30 \mathrm{~min}$. Next, $400 \mu \mathrm{L}$ of the supernatant were dried in a centrifugal evaporator. To the dried cell extracts and the dried releasates were added $50 \mu \mathrm{L}$ of pentafluorobenzyl (PFB) bromide solution $(50 \mu \mathrm{L}$ PFB$\mathrm{Br}+950 \mu \mathrm{L}$ dimethylformamide) and $10 \mu \mathrm{L}$ of diisopropylamine as catalyst. The samples were heated with shaking at $80^{\circ} \mathrm{C}$ for 1 hour and then vortexed with 200 $\mu \mathrm{L}$ of hexane/ethyl acetate $(3: 2)$. The tubes were then centrifuged at $25,000 \times \mathrm{g}$ for $5 \mathrm{~min}$ to precipitate salts. The supernatants were transferred to autosampler vials for GC-MS analyses.

The PFB derivatives were analyzed by ammonia NCIGC-MS via monitoring the [M-181-3(HF) $]^{-}$anions for putrescine (567), $\left[{ }^{2} \mathrm{H}_{4}\right]$ putrescine (571), cadaverine (581), and $\left[{ }^{2} \mathrm{H}_{4}\right]$ cadaverine (585). The $[\mathrm{M}-181]^{-}$anions were monitored for ornithine $(671.1),\left[{ }^{2} \mathrm{H}_{5}\right]$ ornithine (676.2), lysine (658.1) and $\left[{ }^{2} \mathrm{H}_{4}\right]$ lysine (689.1). All GCMS analyses were performed with an Agilent 7890A GC and Agilent 5975C mass analyzer. The GC column was a $30 \mathrm{~m}$ HP-5MS (0.25 mm ID; $0.25 \mu \mathrm{m}$ film).

\section{Immunocytochemistry}

$\mathrm{CHO}$ and NRel cells were grown on glass coverslips (Thermo Scientific) until plates were approximately 50\% confluent. Cells were then fixed by flooding coverslips with $4 \%$ paraformaldehyde in PBS for 10 minutes. Following two 5 min rinses in PBS the cells were blocked with $3 \%$ skim milk in $0.1 \%$ triton X100 PBS for 20 minutes. Cells were stained with an anti-SLC3A2 primary antibody (1:50, Santa Cruz Biotechnology) for 2 hours at room temperature. Excess antibody was removed by rinsing twice in PBS before exposing cells to labeled secondary IgG Alexa 594 antibody (1:400, Invitrogen) for 1 
hr at room temperature. Coverslips where then rinsed twice in PBS before applying Hoescht 33258 for 10 min to stain all nuclei. Finally, cells were rinsed twice more in PBS before mounting in Prolong (Molecular Probes) and viewed by fluorescence microscopy.

\section{Data Analyses}

Data are presented as mean \pm SEM for 6 to 8 plates. Metabolite levels were expressed on a per mg protein basis. GC-MS analyses were performed using 5 point standard curves (reference standards at 0.2 to 10 times the stable isotope internal standard). Data were analyzed by 1 -way ANOVA, followed by the Tukey-Kramer test for multiple comparisons.

\section{Results}

CHO and NRel Diamine Levels

NRel-4 steady-state levels of the diamines putrescine and cadaverine were approximately 3 -fold and 2-fold of $\mathrm{CHO}$ levels, respectively (Table 1 ). There was no difference in the levels of ornithine, the direct precursor of putrescine or in lysine, the direct precursor of cadaverine. Arginine levels also were the same in both cell lines. The diamine exporter, as visualized with antibodies to SLC3A2, was similarly expressed in the cell membrane of both $\mathrm{CHO}$ and N-Rel cells (Figure 1), as reported previously for $\mathrm{CHO}$ cells [18].

\section{Ibuprofen Effects}

Incubations with ibuprofen were found to decrease diamine concentrations in a concentration- and timedependent manner in both $\mathrm{CHO}$ and NRel cells. The concentration-response curves were very steep, with a maximum effect of $50 \%$ decreases in diamine levels (Figure 2). Time-course studies indicated that the actions were time-dependent, achieving maximum response by $24 \mathrm{hr}$ in $\mathrm{CHO}$ cells but by $12 \mathrm{hr}$ in NRel-4 cells (Figure 3 ). The ability of ibuprofen to lower cellular putrescine was demonstrated to lack stereospecificity (data not shown) and involved increased efflux of putrescine (Figure 4). Synthesis of putrescine from labeled ornithine was not altered in NRel-4 cells by ibuprofen treatment (Figure 4).

Table 1 Steady-state levels of amino acids and diamines in untreated $\mathrm{CHO}$ and $\mathrm{N}$-Rel cells.

\begin{tabular}{ccc}
\hline Parameter & CHO & N-Rel \\
\hline Putrescine $(\mathrm{nmol} / \mathrm{mg}$ protein) & $2.06 \pm 0.098$ & $6.69 \pm 0.74^{*}$ \\
\hline Cadaverine $(\mathrm{pmol} / \mathrm{mg}$ protein) & $123.1 \pm 5.1$ & $231.4 \pm 27.0^{*}$ \\
\hline Ornithine $(\mathrm{pmol} / \mathrm{mg}$ protein) & $703.4 \pm 73.4$ & $682.0 \pm 41.9$ \\
\hline Lysine $(\mathrm{nmol} / \mathrm{mg}$ protein) & $15.1 \pm 1.85$ & $13.5 \pm 0.90$ \\
\hline Arginine $(\mathrm{nmol} / \mathrm{mg}$ protein) & $12.2 \pm 0.49$ & $11.6 \pm 0.64$ \\
\hline Data are presented as mean $\pm \mathrm{SEM}(\mathrm{N}=8) .{ }^{*}, \mathrm{p}<0.01$ &
\end{tabular}

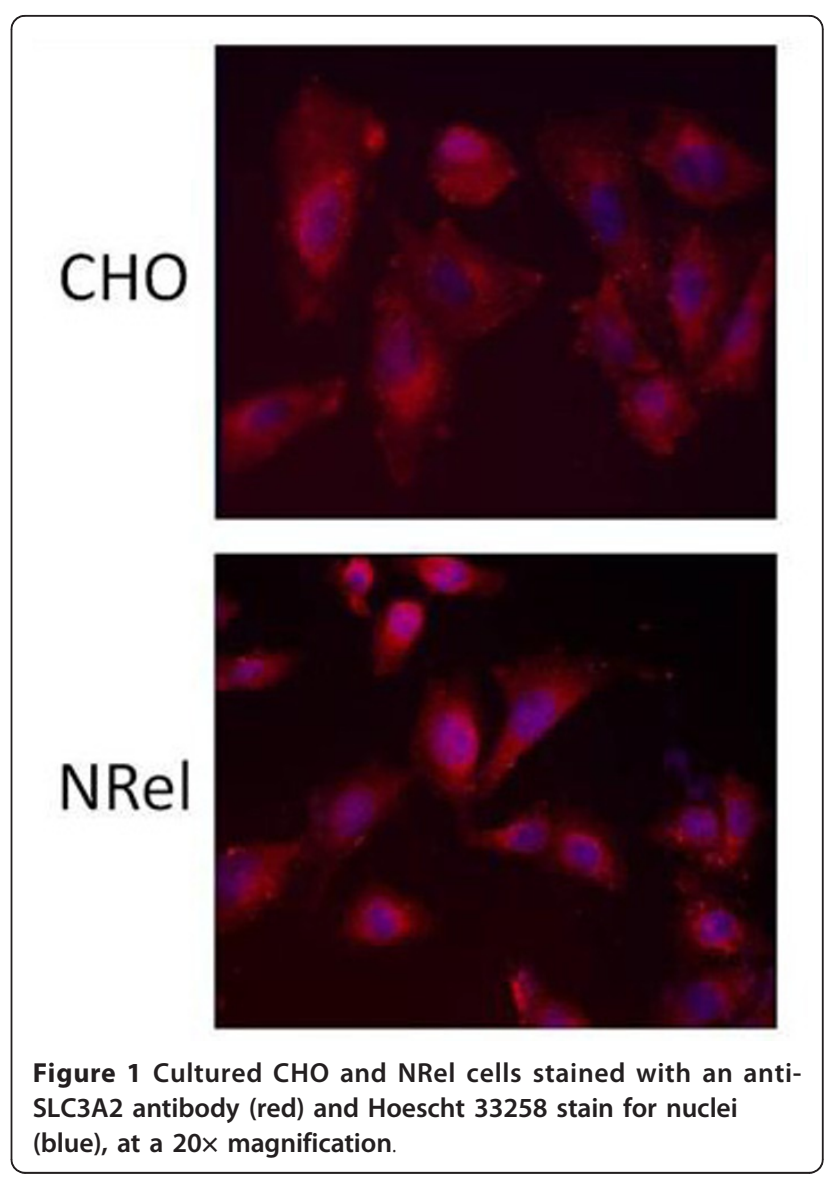

\section{Plasmalogen Effects}

The cellular levels of diamines in NRel-4 cells were restored to normal levels (Figure 5) by augmenting plasmalogens with the ether lipid precursor, PPI-1011 $[25,27]$. Augmenting cellular plasmalogens in $\mathrm{CHO}$ cells also resulted in a small but significant reduction in cellular diamine levels (Figure 5). As with ibuprofen, PPI1011 augmentation of cellular plasmalogens did not alter synthesis of putrescine from labeled ornithine (Figure 4) but did augment cellular export of putrescine (Figure 4).

\section{Discussion}

Cancer chemoprevention strategies [29] represent a clinical approach to augmenting endogenous cytoprotective mechanisms to prevent cancer development and constitute an alternative approach to the never-ending search for the magic bullet that only kills cancer cells. Areas of focus in cancer chemoprevention currently include metabolomics of endogenous anticancer metabolites $[1,2]$; mechanistic studies of the established cancer prevention provided by regular aspirin or NSAID use [7]; studies of the roles and mechanisms of dietary omega-3 fatty acids in cancer prevention $[20,21]$; and down- 

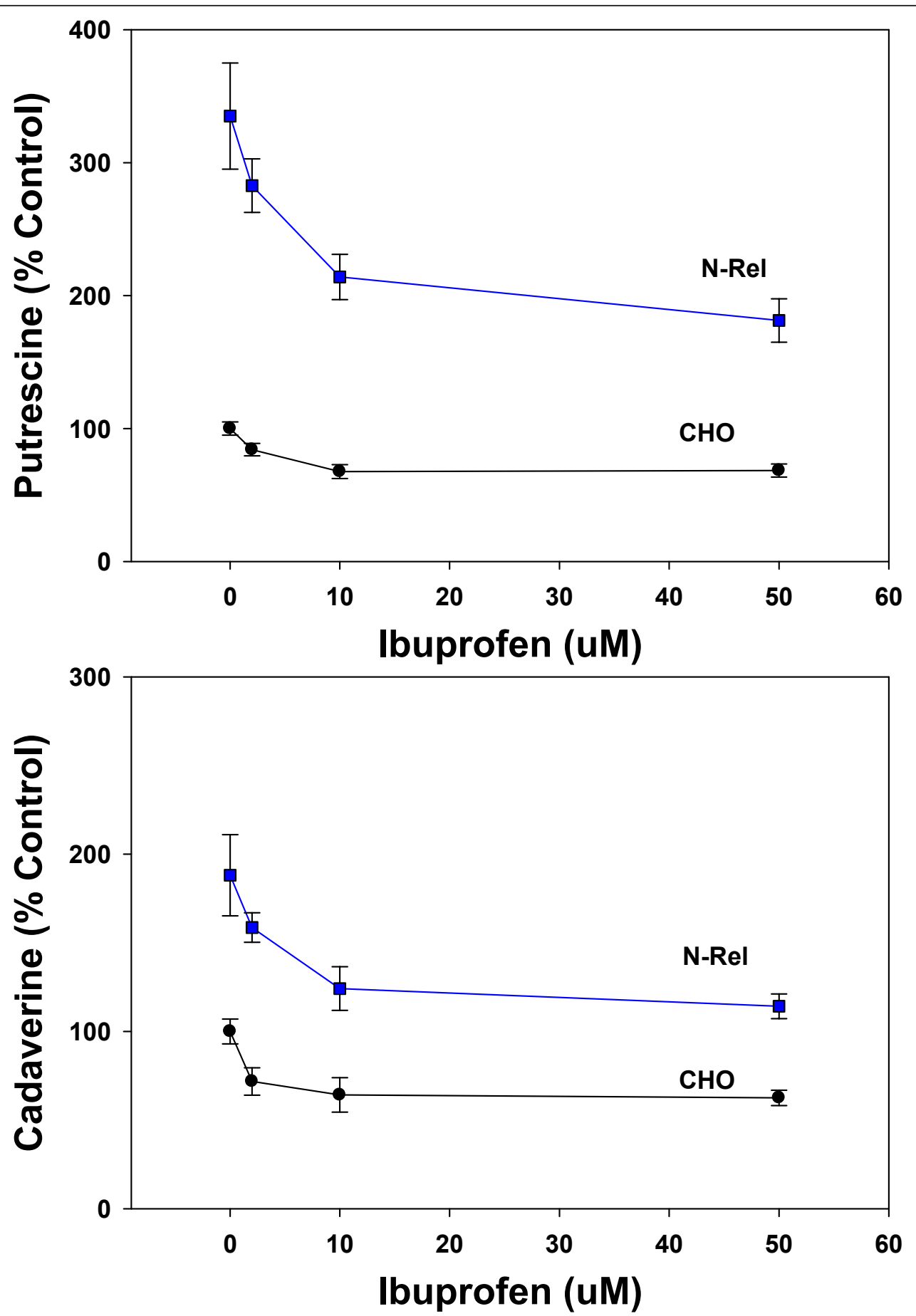

Figure 2 Steep concentration-dependent decreases in cellular putrescine and cadaverine levels in CHO and NRel-4 cells incubated with ibuprofen (0-50 $\mu \mathrm{M})$. Fresh medium and ibuprofen were provided at time 0 and at $24 \mathrm{hr}$. of a $48 \mathrm{hr}$. incubation. Decreases in putrescine and cadaverine levels, with 2, 10 and $50 \mu \mathrm{M}$ ibuprofen, were significant $(P<0.05)$ for both $\mathrm{CHO}$ and NRel-4 cells. $\mathrm{N}=6$. Mean \pm SEM.

regulation of polyamine synthesis to block cancer development $[3-6,8,9,11,13]$.

Putrescine and cadaverine are diamines that have been shown to be increased in a number of cancer tissues, including cervical, colon, endometrial, oral cavity squamous cell, ovarian, pancreatic, and prostate [30-33]. Cellular studies have also demonstrated that a large fraction of polyamine metabolism is comprised of 


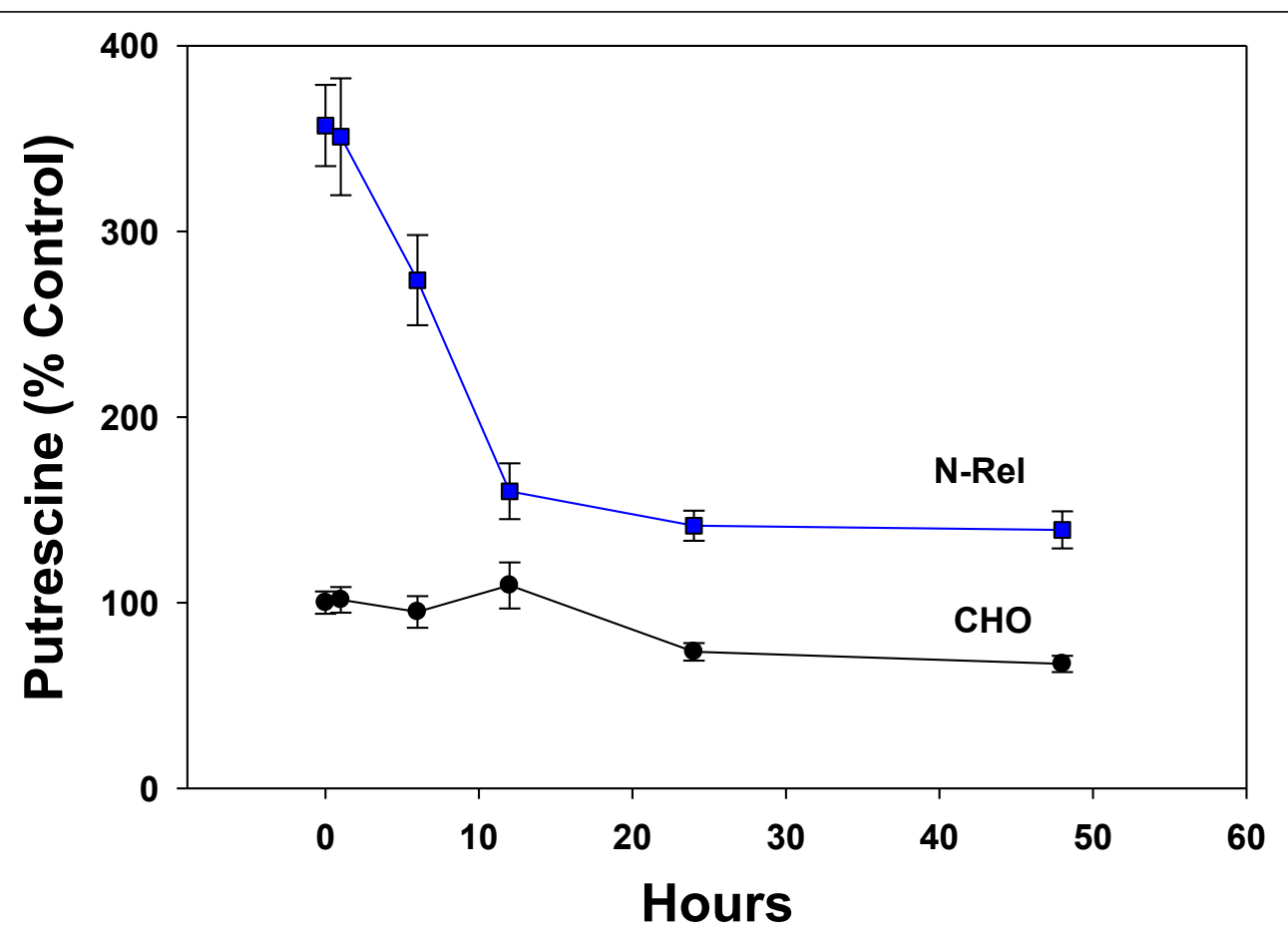

Figure 3 Time course of decreases in cellular putrescine in $\mathrm{CHO}$ and NRel-4 cells during incubation with $50 \mu \mathrm{M}$ ibuprofen. $\mathrm{N}=6$. Mean \pm SEM. Decreases were significant $(p<0.01)$ in NRel cells by $6 \mathrm{hr}$ and by $24 \mathrm{hr}$ in $\mathrm{CHO}$ cells.

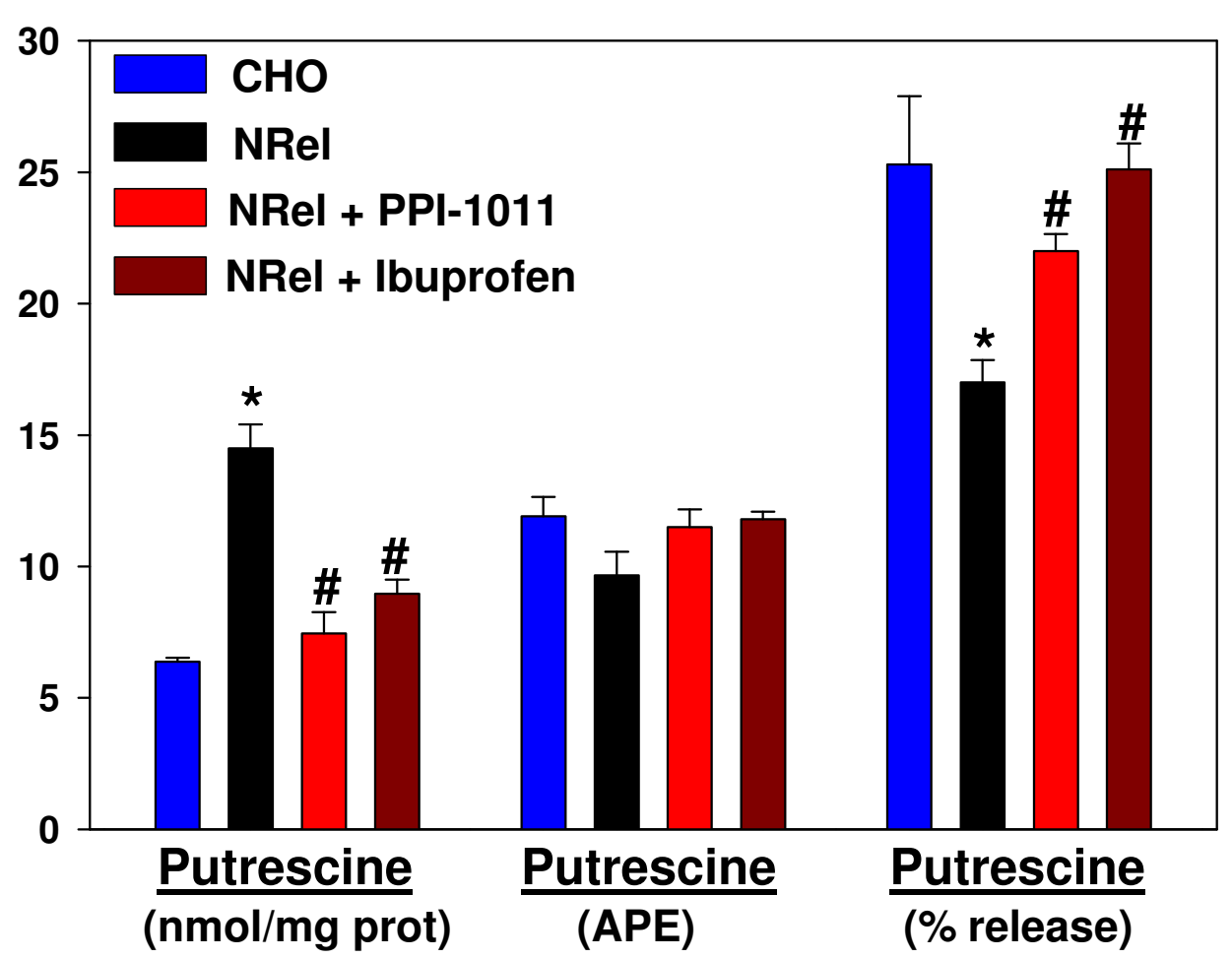

Figure 4 Total cellular putrescine levels (nmol/mg protein); $\left[{ }^{13} \mathrm{C}_{5}\right]$ ornithine decarboxylation to $\left[{ }^{13} \mathrm{C}_{4}\right]$ putrescine, expressed as atom percent excess (APE); and levels of putrescine released into the medium, expressed as a percentage of the total cellular putrescine pool. Labeling of cellular $\left[{ }^{13} \mathrm{C}_{4}\right]$ putrescine with $\left[{ }^{13} \mathrm{C}_{5}\right]$ ornithine $(100 \mu \mathrm{M})$ was a $30 \mathrm{~min}$. incubation. The intracellular ornithine pool was $>97 \%$ $\left[{ }^{13} \mathrm{C}_{5}\right]$ labeled in all cells. Efflux of putrescine was measured using a $1.5 \mathrm{hr}$ incubation. Drug concentrations were $10 \mu \mathrm{M}$ (ibuprofen) and $50 \mu \mathrm{M}$ (PPI-1011) for $48 \mathrm{hr}$. prior to the experiment. $\mathrm{N}=6$. Mean \pm SEM. *, $\mathrm{p}<0.01 \mathrm{vs.} \mathrm{CHO} ; \#, \mathrm{p}<0.01$ vs. untreated NRel. 

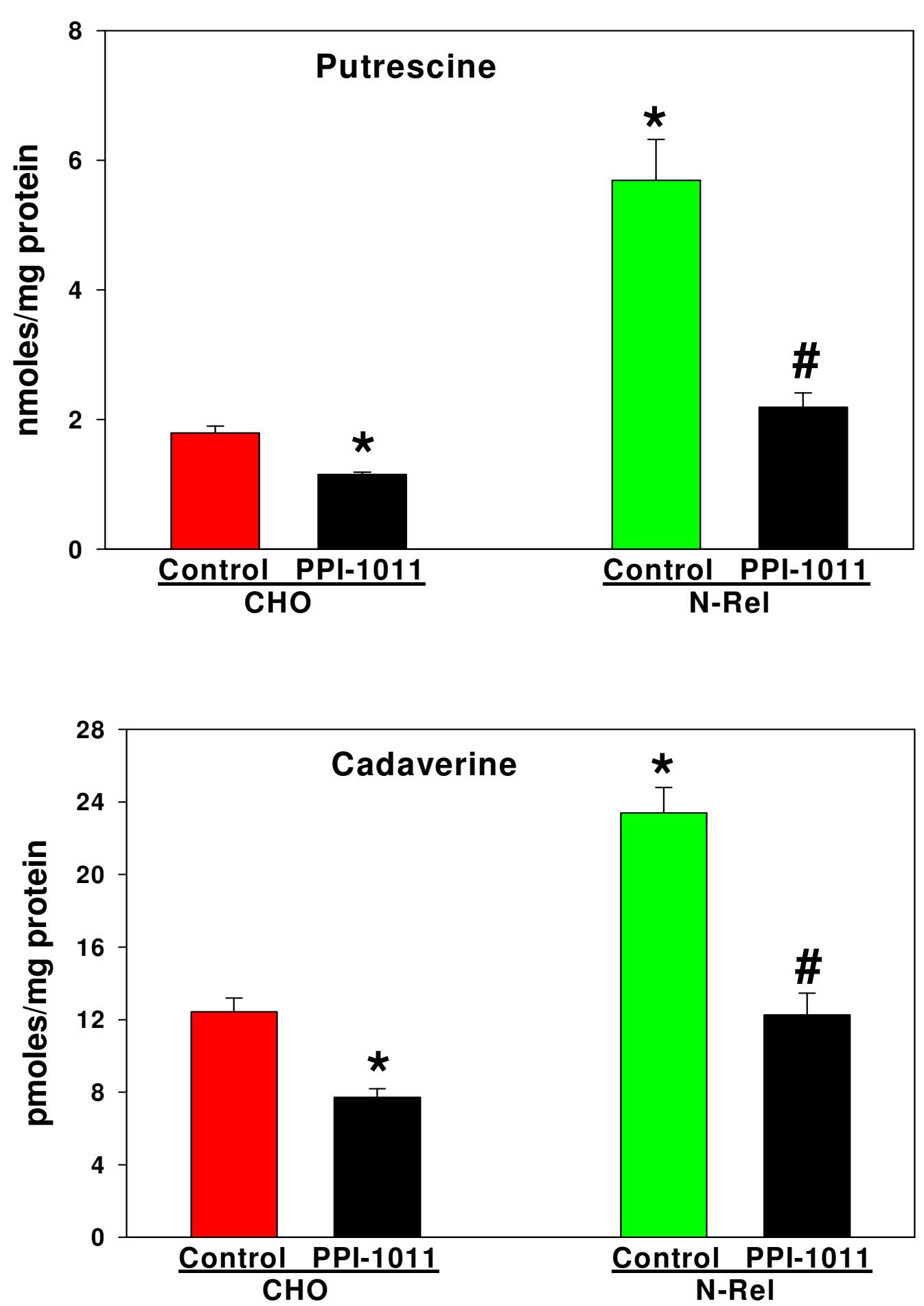

Figure 5 Normalization of NRel-4 putrescine and cadaverine levels after a $72 \mathrm{hr}$ incubation with PPI-1011 (100 $\mu \mathrm{M})$. N =6. Mean \pm SEM. *, $p<0.01$ vs. CHO; \#, $p<0.01$ vs. untreated NRel.

cellular export of putrescine [34] via the diamine exporter $[17,18]$. Similarly, the diamine cadaverine, which is generated by ODC metabolism of lysine (Figure 6), is exported via the diamine exporter $[17,18,35]$. Previous studies of the anti-cancer actions of aspirin have demonstrated that aspirin decreases polyamine synthesis at the level of ODC [12] and increases polyamine metabolism via induction of spermine/spermidine $\mathrm{N}$ - 


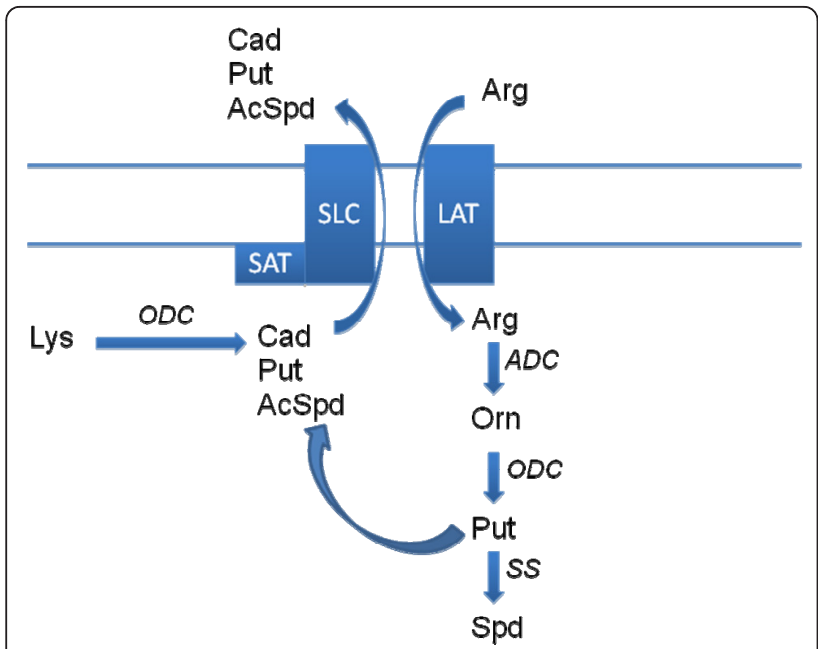

Figure 6 Schematic representation of the diamine exporter AcSpd, acetylspermidine; ADC, arginine decarboxylase; Arg, arginine; CAD, cadaverine; LAT, L-amino acid transporter; ODC, ornithine decarboxylase; Orn, ornithine; Put, putrescine; SLC, SLC3A2 solute carrier; Spd, spermidine; SAT, spermidine/spermine Nacetyltransferase; SS, spermidine synthase.

acetyltransferase [SAT; [36]]. With our studies of ibuprofen, we did not detect any drug effects on polyamine synthesis; however, we did measure increased cellular efflux of putrescine. In this regard, SAT has been shown to be complexed with the diamine exporter, thereby coupling polyamine acetylation and export [18]. Previous data demonstrating induction of SAT with aspirin [36] and our data demonstrating increased diamine exporter function with ibuprofen, suggest that augmentation of the diamine exporter -SAT membrane complex may be a mechanism of action that contributes to the cancer chemoprevention provided by aspirin and NSAIDs. Our data demonstrating that the actions of ibuprofen on cellular diamines are not stereospecific are consistent with previous publications demonstrating that the anti-cancer actions of aspirin [12] and NSAIDs [37] are independent of COX inhibition. These observations also suggest that safer analogs devoid of COX inhibition might be optimal drug candidates for cancer chemoprevention. Use of the ODC inhibitor, difluromethylornithine that reduces cellular polyamine levels is one such approach currently in clinical trials $[8,11]$.

Our data also are the first to demonstrate modulation of the diamine exporter by docosahexaenoic acid (DHA)-containing ethanolamine plasmalogens. Augmentation of plasmalogens with the ether lipid precursor, PPI-1011 [25,27] decreased putrescine levels in $\mathrm{CHO}$ cells and normalized putrescine levels in NRel-4 cells to $\mathrm{CHO}$ cell levels. As with ibuprofen this appears to involve increased putrescine export to control intracellular diamine homeostasis. These data are consistent with previous reports demonstrating that decrements in membrane plasmalogens dramatically alter membrane function via alterations in membrane lipid rafts which in turn leads to deregulation of cholesterol transport $[24,38]$, muscarinic membrane receptors [39] and $\beta$ adrenergic membrane receptors [40,41].

In summary, our understanding of the role(s) of polyamines in the chemoprevention of gastrointestinal malignancies continues to grow. Our data demonstrate the importance of the diamine exporter-SAT complex (Figure 6) in maintaining intracellular diamine levels and further show that a number of dietary and pharmaceutical approaches are available to provide protection against gastrointestinal malignancies.

\section{Acknowledgements}

We thank Dr. R.A. Zoeller for his generous gift of the cell lines. TS was supported by a Canadian National Research Council postdoctoral fellowship.

\section{Author details}

${ }^{1}$ Dept. of Pharmacology, DeBusk College of Osteopathic Medicine, Lincoln Memorial University, 6965 Cumberland Gap Pkwy., Harrogate, TN 37752 USA. ${ }^{2}$ R\&D Dept., Phenomenome Discoveries Inc, 204-407 Downey Road, Saskatoon, SK, S7N 4L8 Canada.

\section{Authors' contributions}

All authors read and approved the manuscript. All authors participated in the study design, supervision of assay QA/QC and data interpretation. TS and PW performed experiments.

\section{Competing interests}

The authors are all involved in the preclinical development of PPI-1011.

Received: 25 October 2011 Accepted: 16 November 2011

Published: 16 November 2011

\section{References}

1. Ritchie SA, Ahiahonu PW, Jayasinghe D, Heath D, Liu J, Lu Y, Jin W, Kavianpour A, Yamazaki Y, Khan AM, Hossain M, Su-Myat KK, Wood PL, Krenitsky K, Takemasa I, Miyake M, Sekimoto M, Monden M, Matsubara H, Nomura F, Goodenowe DB: Reduced levels of hydroxylated, polyunsaturated ultra long-chain fatty acids in the serum of colorectal cancer patients: implications for early screening and detection. BMC Med 2010, 8:13.

2. Arakaki AK, Mezencev R, Bowen NJ, Huang Y, McDonald JF, Skolnick J: Identification of metabolites with anticancer properties by computational metabolomics. Mol Cancer 2008, 7:57.

3. Casero RA Jr, Marton LJ: Targeting polyamine metabolism and function in cancer and other hyperproliferative diseases. Nat Rev Drug Discov 2007, 6:373-90.

4. Casero RA, Pegg AE: Polyamine catabolism and disease. Biochem J 2009, 421:323-38.

5. Martinez ME, O'Brien TG, Fultz KE, Babbar N, Yerushalmi H, Qu N, Guo Y, Boorman D, Einspahr J, Alberts DS, Gerner EW: Pronounced reduction in adenoma recurrence associated with aspirin use and a polymorphism in the ornithine decarboxylase gene. Proc Natl Acad Sci USA 2003, 100:7859-64.

6. Thompson PA, Wertheim BC, Zell JA, Chen WP, McLaren CE, LaFleur BJ, Meyskens FL, Gerner EW: Levels of rectal mucosal polyamines and prostaglandin E2 predict ability of DFMO and sulindac to prevent colorectal adenoma. Gastroenterology 2010, 139:797-805.

7. Harris RE, Beebe-Donk J, Doss H, Burr Doss D: Aspirin, ibuprofen, and other non-steroidal anti-inflammatory drugs in cancer prevention: a critical review of non-selective COX-2 blockade (review). Oncol Rep 2005, 13:559-83. 
8. Meyskens FL Jr, Gerner EW, Emerson S, Pelot D, Durbin T, Doyle K, Lagerberg W: Effect of alpha-difluoromethylornithine on rectal mucosal levels of polyamines in a randomized, double-blinded trial for colon cancer prevention. J Natl Cancer Inst 1998, 90:1212-8.

9. Zell JA, Pelot D, Chen WP, McLaren CE, Gerner EW, Meyskens FL: Risk of cardiovascular events in a randomized placebo-controlled, double-blind trial of difluoromethylornithine plus sulindac for the prevention of sporadic colorectal adenoma. Cancer Prev Res (Phila) 2009, 2:209-12.

10. Mahmud SM, Franco EL, Turner D, Platt RW, Beck P, Skarsgard D, Tonita J, Sharpe C, Aprikian AG: Use of non-steroidal anti-inflammatory drugs and prostate cancer risk: a population-based nested case-control study. PLoS One 2011, 6:e16412.

11. Simoneau AR, Gerner EW, Nagle R, Ziogas A, Fujikawa-Brooks S, Yerushalmi H, Ahlering TE, Lieberman R, McLaren CE, Anton-Culver H, Meyskens FL Jr: The effect of difluoromethylornithine on decreasing prostate size and polyamines in men: results of a year-long phase $\mathrm{llb}$ randomized placebo-controlled chemoprevention trial. Cancer Epidemiol Biomarkers Prev 2008, 17:292-9.

12. Eklou-Kalonji E, Andriamihaja M, Reinaud P, Mayeur C, Camous S, Robert V Charpigny $G$, Blachier F: Prostaglandin-independent effects of aspirin on cell cycle and putrescine synthesis in human colon carcinoma cells. Can J Physiol Pharmacol 2003, 81:443-50.

13. Babbar N, Gerner EW: Targeting polyamines and inflammation for cancer prevention. Recent Results Cancer Res 2011, 188:49-64.

14. Pegg AE: Regulation of ornithine decarboxylase. J Biol Chem 2006, 281:14529-32.

15. Seiler N, Raul F: Polyamines and the intestinal tract. Crit Rev Clin Lab Sci 2007, 44:365-411.

16. Seiler N: Catabolism of polyamines. Amino Acids 2004, 26:217-33.

17. Uemura T, Gerner EW: Polyamine transport systems in mammalian cells and tissues. Methods Mol Biol 2011, 720:339-48.

18. Uemura T, Yerushalmi HF, Tsaprailis G, Stringer DE, Pastorian KE, Hawel L, Byus CV, Gerner EW: Identification and characterization of a diamine exporter in colon epithelial cells. J Biol Chem 2008, 283:26428-35.

19. Wallner S, Schmitz G: Plasmalogens the neglected regulatory and scavenging lipid species. Chem Phys Lipids 2011, 164:573-89.

20. Pauwels EK, Kairemo K: Fatty acid facts, part II: role in the prevention of carcinogenesis, or, more fish on the dish? Drug News Perspect 2008, 21:504-10

21. Giros A, Grzybowski M, Sohn VR, Pons E, Fernandez-Morales J, Xicola RM, Sethi P, Grzybowski J, Goel A, Boland CR, Gassull MA, Llor X: Regulation of colorectal cancer cell apoptosis by the $\mathrm{n}-3$ polyunsaturated fatty acids Docosahexaenoic and Eicosapentaenoic. Cancer Prev Res (Phila) 2009, 2:732-42.

22. Smith RE, Lespi P, Di Luca M, Bustos C, Marra FA, de Alaniz MJ, Marra CA: A reliable biomarker derived from plasmalogens to evaluate malignancy and metastatic capacity of human cancers. Lipids 2008, 43:79-89.

23. Kuo YB, Chan CC, Chang CA, Fan CW, Hung RP, Hung YS, Chen KT, Yu JS, Chang YS, Chan EC: Identification of phospholipid scramblase 1 as a biomarker and determination of its prognostic value for colorectal cancer. Mol Med 2011, 17:41-7.

24. Munn NJ, Arnio E, Liu D, Zoeller RA, Liscum L: Deficiency in ethanolamine plasmalogen leads to altered cholesterol transport. J Lipid Res 2003, 44:182-92.

25. Wood PL, Khan A, Mankidy R, Smith T, Goodenowe DB: Plasmalogen Deficit: A New and Testable Hypothesis for the Etiology of Alzheimer's Disease. Open Access in Alzheimers Disease-Book 2 2011, ISBN 979-953-307022-2.

26. Wood PL, Smith T, Pelzer L, Goodenowe DB: Targeted metabolomic analyses of cellular models of pelizaeus-merzbacher disease reveal plasmalogen and myo-inositol solute carrier dysfunction. Lipids Health Dis 2011, 10:102.

27. Wood PL, Khan MA, Smith T, Ehrmantraut G, Jin W, Cui W, Braverman NE, Goodenowe DB: In vitro and in vivo plasmalogen replacement evaluations in rhizomelic chrondrodysplasia punctata and PelizaeusMerzbacher disease using PPI-1011, an ether lipid plasmalogen precursor. Lipids Health Dis 2011, 10:182.

28. Xie X, Gillies RJ, Gerner EW: Characterization of a diamine exporter in Chinese hamster ovary cells and identification of specific polyamine substrates. J Biol Chem 1997, 272:20484-9.
29. Thompson P, Gerner EW: Of timing and surrogates - A way forward for cancer chemoprevention. Clin Cancer Res 2011, 17:3509-11.

30. Gallesio C, Colombatto S, Modica R: Free and acetylated polyamines as markers of oral cavity tumors. Oral Surg Oral Med Oral Pathol 1994, 77:167-71.

31. Löser C, Fölsch UR, Paprotny C, Creutzfeldt W: Polyamine concentrations in pancreatic tissue, serum, and urine of patients with pancreatic cancer. Pancreas 1990, 5:119-27.

32. Löser C, Fölsch UR, Paprotny C, Creutzfeldt W: Polyamines in colorectal cancer. Evaluation of polyamine concentrations in the colon tissue, serum, and urine of 50 patients with colorectal cancer. Cancer 1990, 65:958-66.

33. Chanda R, Ganguly AK: Diamine-oxidase activity and tissue di- and polyamine contents of human ovarian, cervical and endometrial carcinoma. Cancer Lett 1995, 89:23-8.

34. Tjandrawinata RR, Hawel L, Byus CV: Regulation of putrescine export in lipopolysaccharide or IFN-gamma-activated murine monocytic-leukemic RAW 264 cells. J Immunol 1994, 152:3039-52.

35. Hawel L, Tjandrawinata RR, Fukumoto GH, Byus CV: Biosynthesis and selective export of 1,5-diaminopentane (cadaverine) in mycoplasma-free cultured mammalian cells. J Biol Chem 1994, 269:7412-8.

36. Babbar N, Gerner EW, Casero RA Jr: Induction of spermidine/spermine N1acetyltransferase (SSAT) by aspirin in Caco-2 colon cancer cells. Biochem J 2006, 394:317-24.

37. Grösch S, Tegeder I, Niederberger E, Bräutigam L, Geisslinger G: COX-2 independent induction of cell cycle arrest and apoptosis in colon cancer cells by the selective COX-2 inhibitor celecoxib. FASEB J 2001, 15:2742-4.

38. Mankidy R, Ahiahonu PW, Ma H, Jayasinghe D, Ritchie SA, Khan MA, SuMyat KK, Wood PL, Goodenowe DB: Membrane plasmalogen composition and cellular cholesterol regulation: a structure activity study. Lipids Health Dis 2010, 9:62.

39. Périchon R, Moser AB, Wallace WC, Cunningham SC, Roth GS, Moser HW: Peroxisomal disease cell lines with cellular plasmalogen deficiency have impaired muscarinic cholinergic signal transduction activity and amyloid precursor protein secretion. Biochem Biophys Res Commun 1998, 248:57-61.

40. Styger R, Wiesmann UN, Honegger UE: Plasmalogen content and betaadrenoceptor signalling in fibroblasts from patients with Zellweger syndrome. Effects of hexadecylglycerol. Biochim Biophys Acta 2002, 1585:39-43.

41. Vartanian T, Sprinkle TJ, Dawson G, Szuchet S: Oligodendrocyte substratum adhesion modulates expression of adenylate cyclase-linked receptors. Proc Natl Acad Sci USA 1988, 85:939-43.

doi:10.1186/1476-511X-10-214

Cite this article as: Wood et al: Cellular diamine levels in cancer chemoprevention: modulation by ibuprofen and membrane plasmalogens. Lipids in Health and Disease 2011 10:214.

\section{Submit your next manuscript to BioMed Central and take full advantage of:}

- Convenient online submission

- Thorough peer review

- No space constraints or color figure charges

- Immediate publication on acceptance

- Inclusion in PubMed, CAS, Scopus and Google Scholar

- Research which is freely available for redistribution

Submit your manuscript at www.biomedcentral.com/submit
C Biomed Central 